\title{
A ESCRAVIDÃO EM CENA: UMA LEITURA DE MÃE, DE JOSÉ DE ALENCAR, E O ESCRAVOCRATA, DE ARTUR AZEVEDO E URBANO DUARTE
}

\author{
Rodrigo Cézar Dias \\ Submetido em 23 de maio de 2018. \\ Aceito para publicação em 01 de novembro de 2018.
}

Cadernos do IL, Porto Alegre, n. ${ }^{\circ}$ 57, novembro. p. 9-20

\section{POLÍTICA DE DIREITO AUTORAL}

Autores que publicam nesta revista concordam com os seguintes termos:

(a) Os autores mantêm os direitos autorais e concedem à revista o direito de primeira publicação, com o trabalho simultaneamente licenciado sob a Creative Commons Attribution License, permitindo o compartilhamento do trabalho com reconhecimento da autoria do trabalho e publicação inicial nesta revista.

(b) Os autores têm autorização para assumir contratos adicionais separadamente, para distribuição não exclusiva da versão do trabalho publicada nesta revista (ex.: publicar em repositório institucional ou como capítulo de livro), com reconhecimento de autoria e publicação inicial nesta revista.

(c) Os autores têm permissão e são estimulados a publicar e distribuir seu trabalho online (ex.: em repositórios institucionais ou na sua página pessoal) a qualquer ponto antes ou durante o processo editorial, já que isso pode gerar alterações produtivas, bem como aumentar o impacto e a citação do trabalho publicado.

(d) Os autores estão conscientes de que a revista não se responsabiliza pela solicitação ou pelo pagamento de direitos autorais referentes às imagens incorporadas ao artigo. A obtenção de autorização para a publicação de imagens, de autoria do próprio autor do artigo ou de terceiros, é de responsabilidade do autor. Por esta razão, para todos os artigos que contenham imagens, o autor deve ter uma autorização do uso da imagem, sem qualquer ônus financeiro para os Cadernos do IL.

\section{POLÍTICA DE ACESSO LIVRE}

Esta revista oferece acesso livre imediato ao seu conteúdo, seguindo o princípio de que disponibilizar gratuitamente o conhecimento científico ao público proporciona sua democratização.

http://seer.ufrgs.br/cadernosdoil/index

Quinta-feira, 22 de novembro de 2018. 


\title{
A ESCRAVIDÃO EM CENA: UMA LEITURA DE MÃE, DE JOSÉ DE ALENCAR, E O ESCRAVOCRATA, DE ARTUR AZEVEDO E URBANO DUARTE
}

\author{
SLAVERY ONSTAGE: A CLOSE READING OF JOSÉ DE \\ ALENCAR'S $M \tilde{A} E$, AND ARTUR AZEVEDO AND \\ URBANO DUARTE'S O ESCRAVOCRATA
}

Rodrigo Cézar Dias*

\begin{abstract}
RESUMO: O presente estudo propõe uma leitura das peças Mãe, de José de Alencar, e O escravocrata, de Artur Azevedo e Urbano Duarte, tendo por objetivo central a análise da representação do escravo em ambos os textos, considerando a condição aporética decorrente da escravidão moderna em que o ser humano cativo é percebido legalmente e socialmente como pessoa e como mercadoria. Por meio do cotejo das peças, pretende-se, ainda, mapear os pontos de continuidade e ruptura que podem ser estabelecidos entre as duas obras no que diz respeito à forma dramática e ao tratamento sério dos personagens escravizados.
\end{abstract}

PALAVRAS-CHAVE: Mãe; O escravocrata; escravidão; forma dramática.

ABSTRACT: This study proposes a close reading of José de Alencar's Mãe, and Artur Azevedo and Urbano Duarte's O Escravocrata, in order to analyze the representation of slaves in both plays, taking into account the aporetic condition in which the enslaved human being is perceived legally and socially as both person and commodity. Through the comparison of these plays, I also intend to map out the points of continuity and rupture that can be established between the texts concerning the dramatic form and the serious treatment of enslaved characters.

KEYWORDS: Mãe; O Escravocrata; slavery; dramatic form.

\section{Apontamentos iniciais}

Ao longo de Mimesis, Erich Auerbach discorre sobre a representação da realidade na literatura ocidental, dando centralidade ao tratamento sério dispensado ao cotidiano e à ascensão de camadas populares enquanto objeto de representação problemático-existencial (AUERBACH, 2011, p. 440). Esse movimento de leitura é desenvolvido por meio de um grande panorama cronologicamente organizado que não se pretende exaustivo. Segundo o autor,

[...] o método de me deixar dirigir por alguns motivos de forma paulatina e despropositada e de pô-los à prova mediante uma série de textos que se me tornaram conhecidos e vivos durante a minha atividade filológica, parece-me fecundo e factível; pois estou convencido de que aqueles motivos fundamentais da história da representação da realidade, se os vi corretamente, devem poder ser encontrados em qualquer texto realista escolhido ao acaso (AUERBACH, 2011, p. 494).

Seguindo por esta senda, o presente trabalho propõe um deslocamento do método auerbachiano, partindo de sua leitura acerca da ascensão das camadas populares

* Doutorando em Estudos de Literatura pela Universidade Federal do Rio Grande do Sul, rodrigocezardias@gmail.com. 
enquanto objeto de representação problemático-existencial na literatura ocidental para articular uma análise da representação do escravo em duas peças teatrais produzidas na segunda metade do Oitocentos brasileiro, quais sejam, Mãe, de José de Alencar, e $O$ escravocrata, de Artur Azevedo e Urbano Duarte. Com isso, pretende-se investigar como a condição aporética decorrente da escravidão moderna em que o ser humano cativo é percebido legalmente e socialmente como pessoa e como mercadoria é refratada nesses textos literários. Por meio do cotejo das peças, busca-se, ainda, mapear os pontos de continuidade e ruptura que podem ser estabelecidos entre as duas obras no que diz respeito à forma dramática e ao tratamento sério dos personagens escravos e dos personagens proprietários de escravos.

\section{A representação do escravizado no teatro}

No ano de 1875, a estreia da peça $O$ jesuíta, de José de Alencar, suscita uma polêmica literária travada entre o autor e Joaquim Nabuco nas páginas do jornal $O$ Globo, vindo a ser reunida em volume por Afrânio Coutinho em 1965 sob o título $A$ polêmica Alencar-Nabuco. A refrega tem por estopim a crítica de Nabuco ao caráter datado da obra, produzida em 1861 e não alterada para a representação em 1875, o que, segundo ele, seria um dos motivos por trás da pouca acolhida da peça pelo público fluminense. Alencar, por sua vez, transfere a "responsabilidade" pelo fracasso da peça para o público, que, em seu julgamento, não valorizava o teatro nacional. A partir dessa discussão inicial, Nabuco submete a produção romanesca e dramática de Alencar a um severo exame no folhetim do Globo, sob o título "Aos domingos: estudos sobre o Sr. J. de Alencar", sendo que as réplicas do romancista começariam a ser veiculadas no mesmo espaço do jornal, sob o título "Às quintas".

Para os fins desta leitura, é oportuno destacar uma das críticas realizadas por Nabuco à peça $O$ demônio familiar, centrada na representação do escravo e de sua fala em cena:

\footnotetext{
Essa linguagem de telegrama não é falada entre nós; mas se o fosse, ainda não teria o direito de passar da boca dos clown, pintados de preto, dos nossos circos para a dos atores. O negro, nascido no país e criado na família do senhor, como esse Pedro, que teve a mesma educação dos filhos da casa, não suprime assim o artigo e não fala uma língua que nos parece bárbara. Falasse-a porém, ela não devia ser repetida em cena. Já é bastante ouvir nas ruas a linguagem confusa, incorreta dos escravos; há certas máculas sociais que não se devem trazer ao teatro, como o nosso principal elemento cômico, para fazer rir. O homem do século XIX não pode deixar de sentir um profundo pesar, vendo que o teatro de um grande país, cuja civilização é proclamada pelo próprio dramaturgo escravagista (o seu teatro só abala a escravidão em nosso espírito, não no dele), acha-se limitado por uma linha negra, e nacionalizado pela escravidão. Se isso ofende o estrangeiro, como não humilha o brasileiro! (COUTINHO, 1965, p. 106, grifos meus).
}

Temos, pois, nas palavras do jovem autor, que viria a se destacar por conta de sua militância abolicionista, uma reprovação enfática não só da representação supostamente inverossímil da fala do escravo, mas também, em boa medida, da própria representação de indivíduos escravizados no palco. Alencar, por sua vez, posiciona-se a favor da representação da escravidão no palco como um meio por ele utilizado para 
defender a causa da emancipação espontânea ${ }^{1}$, patenteando com "o prestígio da cena os perigos e horrores dessa chaga social" (COUTINHO, 1965, p. 120).

Para pensarmos essa questão, podemos mobilizar a leitura desenvolvida por Jacques Rancière em seu artigo intitulado "O efeito de realidade e a política da ficção". $\mathrm{O}$ autor parte da análise empreendida por Roland Barthes em "O efeito de realidade", texto que

começa focando um detalhe retirado do conto de Flaubert "Um coração simples". Ao descrever a sala da casa onde sua personagem vive, o escritor diz que "um velho piano sustentava, sob um barômetro, um monte piramidal de caixas e caixotes". Obviamente esse barômetro não tem utilidade alguma e o monte piramidal não nos deixa ver nada determinado. Como afirma Barthes, eles "elevam o custo da informação da narrativa" (RANCIÈRE, 2010, p. 75).

Ao contrário da interpretação de Barthes, que considera o detalhe inútil como o "real que prova sua realidade por sua própria inutilidade e carência de sentido" (RANCIÈRE, 2010, p. 76), Rancière defende a hipótese de que o

\begin{abstract}
ocioso barômetro expressa uma poética da vida ainda desconhecida, manifestando a capacidade de qualquer um (por exemplo, da velha empregada de Flaubert [Felicité, protagonista de "Um coração simples]) de transformar a rotina do dia-a-dia na profundeza da paixão, seja por um amante, um senhor, uma criança, seja por um papagaio. $O$ efeito de realidade é um efeito de igualdade (RANCIËRE, 2010, p. 79, grifo meu).
\end{abstract}

Assim, a representação desse índice do cotidiano apontaria para uma "democracia literária", materializada por uma redistribuição do sensível que possibilitaria um tratamento sério de indivíduos das camadas populares, outrora relegados apenas ao estilo baixo, o que vai ao encontro da leitura do realismo moderno empreendida por Erich Auerbach.

Desse modo, penso que a representação da escravidão, tanto no teatro de Alencar como no de Artur Azevedo e Urbano Duarte, apresenta potencialidades expressivas interessantes apesar de suas fraturas - e, em certa medida, em decorrência delas. Na tentativa de evidenciar esses elementos, parto para a discussão a respeito de cada uma das obras, buscando subsídios para cotejá-las e situá-las na dimensão do debate público que as atravessava.

\title{
3. Os olhos cansados de Joana: o proprietário-filho e sua escrava-mãe
}

\footnotetext{
${ }^{1}$ A emancipação espontânea se balizava pela perspectiva de que o Estado não deveria intervir nas relações de propriedade envolvendo escravagistas e escravizados, incumbindo aos próprios senhores de escravos a responsabilidade moral de alforriar as pessoas que eles mantinham em cativeiro. Conforme Alencar, em discurso proferido em 1871, "a causa da emancipação espontânea há muito que está vencida no coração do povo brasileiro; diariamente se reproduzem os exemplos de manumissões. É admirável o aspecto que representa o nosso País; todas as classes porfiam na prática desses atos. A estatística, em 1860, dá-nos uma prova da rapidez com que marcha essa revolução social. Só na cidade do Rio de Janeiro, houve 14.000 alforrias. Este algarismo é eloquente; ele significa que em talvez 20 anos a escravidão estaria, por si mesma, extinta" (ALENCAR, 1977, p. 242 apud SIMÕES, 2011, p. 192).
} 
Sendo representado pela primeira vez em 1860, o drama em quatro atos Mãe, de José de Alencar, tem sua ação localizada no Rio de Janeiro de 1855, possuindo como cenário um prédio que tem por moradores, no primeiro andar, o funcionário público Gomes e sua filha Elisa e, no andar superior, o estudante de medicina Jorge. Alinhavando os dois núcleos figura Joana, escrava - e mãe - do estudante, que ajudava nos afazeres domésticos na residência de Gomes desde que o último escravo do funcionário público fora penhorado, estimulando o embrião de namoro entre Elisa e Jorge. Temos, portanto, dois proprietários de escravos despossuídos: um funcionário público endividado por conta da doença que o acometeu após a morte da esposa e um estudante cuja renda provém de aulas de piano e de francês, de algumas traduções e, principalmente, da exploração da força de trabalho de Joana, que costura e lava "para fora".

Até então, Joana conseguira ocultar o fato de que era mãe de Jorge, sendo que a única pessoa que tinha conhecimento disso era o Dr. Lima, médico que supostamente teria pago pelos estudos e demais despesas relacionadas à criação do jovem - que o tem como "segundo pai" -, quando, em verdade, fora Joana que arcara com esses gastos. No recorte temporal em que se passa o drama, Lima retorna da Europa, encontrando Joana ainda escravizada, o que lhe causa surpresa e alguma inquietação. Entretanto, o médico chega a tempo de testemunhar o proprietário-filho alforriar a escrava-mãe, visto que Jorge saldara a hipoteca que havia contraído sobre ela e estava financeiramente livre para saldar sua consciência.

Desse modo, coexiste em Jorge tanto a afeição de filho para com Joana, que não permite que ele a veja como escrava, quanto a relação de senhor de escravo que se utiliza de ao menos duas possibilidades de exploração financeira de sua propriedade, considerando a hipoteca e, além disso, o trabalho da escrava, que o sustentara até então a custo de sua visão fatigada. Quando Lima pergunta a Jorge por seus rendimentos, o estudante responde que obtém, por meio das lições de francês e de piano, cerca de cem mil réis por mês, o que na visão do médico é pouco.

\footnotetext{
JORGE - Faço também algumas traduções que me deixam às vezes um extraordinário. Joana por seu lado ganha...

JOANA - Quase nada, nhonhô! Já estou velha. Não coso mais de noite.

JORGE - Nem eu quero. Foi de passares as noites sobre costura que ias perdendo a vista.

DR. LIMA - Faz bem em tratá-la com amizade, Jorge. É uma boa...

JOANA - Sou uma escrava como as outras.

JORGE - É uma amiga como poucas se encontram (ALENCAR, 1940?, p. 78).
}

No andar inferior do prédio, por sua vez, há um recrudescimento da situação financeira precária de Gomes. Devendo para o senhorio e para Peixoto, um agiota, o funcionário público é acusado por este de ter falsificado uma letra, tendo até o final do dia para reaver o valor. Não conseguindo lidar com a acusação, considera o suicídio por envenenamento como uma saída mais honrosa do que enfrentar as galés. Gomes quase recorre a Jorge, mas é obstado pela vergonha; Elisa, por sua vez, expõe a situação para o namorado, entregando a ele o frasco de veneno com que o pai lhe acenara o suicídio.

Jorge busca reunir recursos, pedindo um empréstimo a Lima, que só conseguiria a quantia no dia seguinte, visto que a alfândega já estava fechada. Joana, então, rasga sua carta de alforria e propõe que o estudante a hipoteque, argumentando que Lima poderia resgatar o valor no outro dia, saldando a dívida. Após breve resistência, Jorge aceita renovar a hipoteca contraída com Peixoto, o mesmo credor/acusador de Gomes; desta vez, entretanto, o negociante impõe que a operação realizada seja um penhor. Ao 
observar o documento que iria registrar a transação, Jorge percebe, ainda, que se tratava de um contrato de venda a retro, dispondo o prazo de um mês para que ele pagasse a dívida e recuperasse sua escrava - o que consiste em uma terceira via de exploração de Joana enquanto propriedade.

Após recusar a proposta veementemente, Jorge assina de imediato o documento tão logo Elisa entra em cena, resgatando a letra falsificada. Após a saída da jovem, que vai avisar o pai da solução alcançada - ainda que não tenha conhecimento do negócio do qual provém o dinheiro -, Joana parte com Peixoto. No dia seguinte, ela retorna para a casa de Jorge, aproveitando um descuido do usurário; logo após, chega Lima com o dinheiro que prometera emprestar. A fim de saldar a dívida, Jorge busca Peixoto, sem sucesso, retornando para casa e recebendo, em seguida, uma visita de Gomes e de Elisa que tem por objetivo o acerto do noivado.

Enquanto o estudante sai de cena com o futuro sogro para mostrar os aposentos a ele destinados em sua casa, Peixoto bate à porta, procurando por sua escrava. Acreditando que Joana estava forra, Lima não consegue entender a situação, até que o usurário lhe mostra o documento que formalizara a negociação. Com Joana ao fundo da cena e Jorge e Gomes retornando ao proscênio, Lima não contém mais o segredo que guardara.

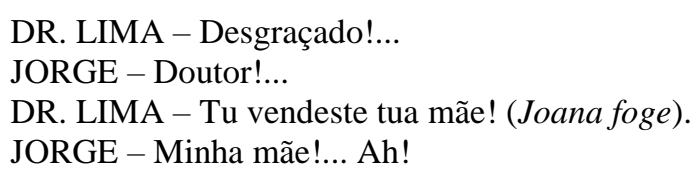

DR. LIMA - Tua mãe, sim!... Digo-o alto! porque te sei bastante nobre para não renegares aquela que te deu o ser (ALENCAR, 1940?, p. 201).

Após pagar a dívida, Jorge procura por Joana, enquanto Gomes rejeita a hipótese de casamento por conta da ascendência do noivo. Por fim, a mãe recém-descoberta ingere o veneno adquirido por Gomes e recebido por Jorge das mãos de Elisa. No desfecho, Peixoto é preso por falsificação e Joana morre nos braços do filho, o que comove também a Gomes, que abençoa o casamento dos jovens namorados.

Em "A importação do romance e suas contradições em Alencar", Roberto Schwarz retoma a discussão entre Alencar e Nabuco, apontando que

\footnotetext{
Nabuco põe o dedo em fraquezas reais, mas para escondê-las; Alencar pelo contrário incide nelas tenazmente, guiado pelo senso da realidade, que o leva a sentir, precisamente aí, o assunto novo e o elemento brasileiro. Ao circunscrevê-las sem as resolver, não faz grande literatura, mas fixa e varia elementos dela - um exemplo a mais de como é tortuoso o andamento da criação literária (SCHWARZ, 2000, p. 40).
}

A tese de Schwarz que percorre o ensaio acerca da importação da forma romanesca por Alencar pode ser sintetizada na ideia de que o defeito de composição decorrente da adoção acrítica do modelo europeu torna-se acerto da imitação, sendo incorporado no plano do conteúdo. Assim, entra em jogo uma combinação esdrúxula, mas real, que conjuga clientelismo e ideologia liberal - e, pensando mais especificamente em Mãe, podemos acrescentar a combinação de escravismo e capitalismo.

$\mathrm{Na}$ peça, somos apresentados a duas configurações de escravocrata, que, conforme a leitura da obra, podem ser vistas como o "bom senhor" e o "mau senhor". O primeiro caso é representado por Jorge, que sequer consegue verbalizar a condição de escrava de Joana, tendo-a como uma "segunda mãe" (ainda que escravizada), como podemos observar na cena em que o estudante a entrega às mãos de Peixoto: 
JORGE - Tenho apenas uma súplica a fazer-lhe.

PEIXOTO - Que diremos?

JORGE - Durante o tempo que esta... que Joana vai estar em sua casa.

PEIXOTO - Que é minha escrava, quer o senhor dizer.

JORGE - Peço-lhe que a trate com doçura. Está habituada a viver comigo, mais como uma companheira do que...

PEIXOTO - Escusa pedir-me isto. Sou bom senhor. O caso é saberem levarme. Anda, mulata! Vamos (ALENCAR, 1940?, p. 159-160).

As reticências de Jorge são completadas por Peixoto, o negociante pérfido que não faz mais do que seguir à risca a ideologia escravagista que mercantiliza o indivíduo escravizado - e, por sua vez, pode ser vista como uma expressão radicalizada da racionalidade "desumana", de tipo mecânico, das esferas econômica e política, que, segundo Schwarz, subordina ao mesmo título "objetos e força de trabalho" (SCHWARZ, 2000, p. 55).

De forma periférica, temos ainda o caso de Lima, que é referido em uma conversa entre Joana e Vicente, um escravo liberto que pertencera ao médico e durante a ação do drama exercia a função de oficial de justiça. Ao lembrarem do passado em que ambos viviam sob a tutela de Lima junto a Jorge, o tom é saudoso, quase nostálgico:

VICENTE - É mesmo, tia Joana. Bom tempo! Sr. doutor [Lima] só fazia ralhar. Tirante disso, era bom amo.

JOANA - Tem tido notícias dele?

VICENTE - Depois que foi viajar, nunca mais soube por onde anda.

JOANA - E a comadre Rosa que ele vendeu a um homem da rua da Alfândega?

VICENTE - Essa morreu... O André está cocheiro na praça.

JOANA - Cada um para sua banda (ALENCAR, 1940?, p. 62).

O mesmo Lima, que insiste na libertação de Joana por Jorge, vendeu Rosa, comadre para Joana e propriedade para ele. Assim, a possibilidade de ver o escravo como humano para o médico parece ser condicionada por algum vínculo específico. Retomando Rancière, agora por meio de A partilha do sensível, podemos pensar em quais são as possíveis condições para que Lima - e, em certa medida, Jorge discriminem quais são os escravos comercializáveis e quais são os escravos que devem ser libertados. Segundo o autor, partilha do sensível é

\footnotetext{
o sistema de evidências sensíveis que revela, ao mesmo tempo, a existência de um comиm e dos recortes que nele definem lugares e partes respectivas. Uma partilha do sensível fixa portanto, ao mesmo tempo, um comum partilhado e partes exclusivas. Essa repartição das partes e dos lugares se funda numa partilha de espaços, tempos e tipos de atividade que determina propriamente a maneira como um comum se presta à participação e como uns e outros tomam parte nessa partilha (RANCIÈRE, 2009, p. 15, grifos do autor).
}

Joana é vista por Lima como alguém que deveria participar desse comum, julgando que a relação de maternidade sobrepujaria a relação de propriedade que a une a Jorge; este, ao descobrir em sua escrava sua mãe, posiciona-se da mesma maneira. Joana, contudo, em sua visão de excluída do comum, percebe que a possibilidade de sua entrada nesse espaço consistiria na exclusão de seu filho do mesmo espaço, o que é parcialmente comprovado por Gomes, que inicialmente recusa a proposta de casamento por conta da ascendência de Jorge. A resolução dos problemas só virá com o suicídio de Joana, que "purga" simbolicamente o estigma de seu filho ao negar a si mesma, 
lembrando-se que ela morre sob a condição legal de escrava, visto que sua carta de alforria fora rasgada.

\section{Os escravocratas}

Conforme pródomo assinado por Artur Azevedo e Urbano Duarte, o drama em três atos $O$ escravocrata, escrito em 1882 "e submetido à aprovação do Conservatório Dramático Brasileiro sob o título A família Salazar, não mereceu o indispensável placet" (AZEVEDO, 1985, p. 179). Assim, a obra foi publicada em 1884, tendo por ambição declarada pelos autores o esforço em concorrer "com o pequenino impulso das nossas penas para o desmoronamento da fortaleza negra da escravidão" (AZEVEDO, 1985, p. 180).

Se na peça de Alencar Joana é lastro para empréstimo e, por fim, propriedade vendida a retro, temos n'O escravocrata um início que leva ao extremo a institucionalização do comércio escravagista, apresentando como cenário do primeiro dos três atos uma casa de alugar escravos. Na cena inicial, Salazar, o escravocrata, instrui seu caixeiro a respeito da entrega de "quarenta e quatro cabeças", incluindo Lourenço, um de seus escravos particulares, de quem ele pretendia se livrar. Em seguida, conversa com seu sócio, Sebastião, acerca dos negócios, em um diálogo que exerce função expositiva, ilustrando a crueldade dos comerciantes de escravos e sinalizando o impacto da campanha abolicionista:

SALAZAR - Negro não tem licença para estar doente. Enquanto respira, há de poder com a enxada, quer queira, quer não.

SEBASTIÃO - De acordo, mas hoje anda aí em moda tratá-los bem... com humanidade... não sei que mais...

SALAZAR - Tolices! Humanidade para negro! Para moléstia de negro há um remédio supremo, infalível e único: o bacalhau. Dêem-me um negro moribundo e um bacalhau, que eu lhes mostrarei se o não ponho lépido e lampeiro com meia dúzia de lambadas!

SEBASTIÃO - Perfeitamente de acordo. Mas, quer queiramos, quer não, temos de contemporizar com essas ideias... Os tais senhores abolicionistas...

SALAZAR (Erguendo-se e descendo ao proscênio.) - Psiu! Não me fales nessa gente, pelo amor de Deus! Só o nome dessa cáfila de bandidos que ultimamente me têm feito perder mais de oitenta contos, irrita-me de um modo incrível! (AZEVEDO, 1985, p. 184).

Ainda nesta cena, quando questionado por Sebastião acerca de Lourenço, Salazar confirma que ele será enviado à sua fazenda por ser muito "emproado", ainda que Gabriela, sua esposa, o proteja, alegando que ele seria cria da casa. Ao longo da peça, descobrimos que a real causa dessa proteção é o fato de ter havido uma relação sexual, talvez amorosa, entre ambos, cujo fruto foi Gustavo, que fora criado como filho legítimo por Salazar sem que este duvidasse de sua paternidade.

Gustavo, por sua vez, apresenta de início um alinhamento à posição de Salazar, opondo-se aos abolicionistas que atacam seu suposto pai por meio de publicações na imprensa. Entretanto, quando presencia Salazar prestes a chicotear Lourenço por este não abaixar a vista, intervém:

GUSTAVO - Peço por ele, meu pai! Lourenço é um escravo dócil e obediente (A Lourenço, com brandura.). Abaixa a vista, Lourenço (Lourenço obedece.). Pede humildemente perdão a meu pai de lhe não haveres obedecido incontinenti. 
LOURENÇO - Peço humildemente perdão a meu senhor... (AZEVEDO, 1985, p. 188-189).

O seu comportamento parece oscilar, portanto, entre o de Salazar, em sua aversão aos negros, e o de Gabriela, em sua afeição por Lourenço, podendo ser exemplificado pela seguinte fala que dirige a Salazar: "[...] para esta raça amaldiçoada só há três princípios: o eito, o bacalhau e a força! Mas não posso deixar de abrir uma exceção para o Lourenço...” (AZEVEDO, 1985, p. 189).

Como traço importante de sua personalidade temos, ainda, sua propensão para 0 jogo, sendo que uma de suas preocupações centrais no drama é arranjar quatrocentos mil réis para saldar suas dívidas, quantia que não lhe é concedida por Salazar, que ironicamente o incita a ganhar o dinheiro com o "suor de seu rosto". Será Lourenço, com suas economias (cento e vinte mil, seiscentos e vinte réis), que ajudará Gustavo em um primeiro momento, ao perceber que o filho está endividado por conta do jogo.

Ao final do primeiro ato, Gabriela e Carolina, filha do casal Salazar, conseguem convencer o escravocrata a manter Lourenço junto à família, submetendo-se à condição única de não intervirem quando o patriarca julgasse que o escravo merecesse sofrer castigos físicos. Com isso, Lourenço pôde testemunhar, já na casa dos Salazar, no segundo ato, a acusação feita por um credor de que Gustavo teria falsificado uma letra, assinando-a por Salazar, no valor de quinhentos mil réis. Lourenço toma o documento das mãos do credor e o rasga, prometendo que o pagaria dentro de pouco tempo, enquanto Gabriela traz joias para cobrir a dívida; o credor, em uma comoção inverossímil, aceita que o pagamento seja feito quando possível.

Em mais uma tentativa de obter dinheiro para apostar no jogo e resgatar a letra falsificada, Gustavo decide roubar diretamente do gabinete de Salazar. Sendo impedido por Lourenço, que lhe toma o dinheiro, desfere uma bofetada contra o rosto de seu escravo-pai, que acaba por lhe revelar o segredo que guardava há vinte e dois anos:

LOURENÇO (Em tom singular.) - Esta bofetada será um direito perante os homens, mas perante Deus é um sacrilégio. Eu...

GABRIELA (Correndo para Lourenço.) - Lourenço, não o digas!

LOURENÇO (Desvencilhando-se.) - Eu sou teu pai! (Tomando Gabriela pelo braço.) Negue! Negue, se é capaz! (Gabriela dá um grito e cai desfalecida. Longa pausa. Gustavo fulminado recua paulatinamente, fitando Lourenço com o olhar desvairado. Entra Salazar, que estaca no fundo ao ver a cena.) (AZEVEDO, 1985, p. 202-203).

O terceiro ato se passa na fazenda dos Salazar, com Gustavo recuperando-se de "fortíssima comoção cerebral" (conforme o diagnóstico de Eugênio, médico da família e pretendente abolicionista de Carolina) e com Gabriela internada no Hospício de Pedro II. Lourenço, responsabilizado pelo furto malogrado de Gustavo, conseguira fugir, sendo recapturado por um empregado de Salazar. A título de desfecho do drama, Lourenço se enforca, evitando que Gustavo seja ferido por Salazar, o que suscita uma revolta dos escravos da fazenda, que se armam de foices e machados contra o escravocrata. A sublevação é interrompida, todavia, pelo pedido de misericórdia de Carolina, o que faz com que os escravos larguem suas armas e saiam "resmungando" sem que saibamos se a revolta seria abortada ou se resultaria em fuga. Gustavo, por fim, é encontrado morto junto ao cadáver do pai.

\section{A escravidão no palco: continuidade e ruptura}


Para realizarmos um cotejo que não peque por anacronia, não podemos deixar de levar em consideração a distância temporal que separa $O$ escravocrata, escrito em 1882 e publicado em 1884, de Mãe, escrito em 1855 e estreado em 1860. Nesse intervalo, o movimento abolicionista ganhou corpo e representatividade na esfera pública brasileira, utilizando-se de diversos canais de comunicação, como jornais, opúsculos e meetings, e contando com a criação de diversos clubes e associações.

Enquanto Alencar se manifestava publicamente como partidário da emancipação espontânea, Azevedo e Duarte eram abolicionistas declarados, sendo que o primeiro deles chegou a realizar uma leitura do primeiro ato de $O$ escravocrata em reunião da Abolicionista Cearense, leitura que, conforme comentário publicado na seção editorial da Gazeta de Noticias, fora "interrompida constantemente pela hilariedade" (ABOLICIONISTA..., 1884, p. 2).

Ao contrário de Mãe, que possui raros momentos de distensão, O escravocrata apresenta uma mescla de estilos acentuada, reservando a alguns personagens funções de alívio cômico, principalmente no que se refere às figuras de Josefa, irmã de Salazar, e do ex-abolicionista Serafim, empregado do escravocrata. A primeira é caracterizada como uma senhora provinciana e tagarela, constantemente ignorada por todos, que odeia pessoas negras. O segundo, por sua vez, é representado como um oportunista que, ao ver que o abolicionismo não estava sendo "lucrativo", oferece seus trabalhos para o escravocrata; ao final do drama, com a sublevação dos escravos, abandona o serviço, considerado demasiado perigoso, resolvendo voltar a ser "abolicionista".

Além desse abolicionista de ocasião, temos a figura de Eugênio, que marca seu posicionamento por meio de seu discurso, mas evita entrar em choque com o pai de sua pretendente, fato que Josefa não deixa passar em branco por meio de uma indireta endereçada a ele, a quem diz ser um dos "sujeitinhos que são abolicionistas, mas que andam à coca de meninas que têm escravos" (AZEVEDO, 1985, p. 196). O personagem, estabelecido na oscilação entre o amor pela namorada e o engajamento pela causa, justifica sua hesitação a Gabriela e Carolina posicionando-se da seguinte forma:

[...] Se bem que não apresente como paladino, faço modestamente tudo quanto posso pela causa da emancipação dos escravos (Pausa.). Estou perfeitamente convicto de que a escravidão é a maior das iniquidades sociais, absolutamente incompatível com os princípios em que se esteiam as sociedades modernas. É ela, é só ela a causa real do nosso atraso material, moral e intelectual, visto como, sendo a base única da nossa constituição econômica, exerce a sua funesta influência sobre todos os outros ramos da atividade social que se derivam logicamente da cultura do solo. Mesmo no Rio de Janeiro, esta grande capital cosmopolita, feita de elementos heterogêneos, já hoje possuidora de importantes melhoramentos, o elemento servil é a pedra angular da riqueza. $\mathrm{O}$ estrangeiro que o visita, maravilhado pelos esplendores da nossa incomparável natureza, mal suspeita das amargas decepções que o esperam. Nos ricos palácios como nas vivendas burguesas, nos estabelecimentos de instrução como nos de caridades, nas ruas e praças públicas, nos jardins e parques, nos pitorescos e decantados arrabaldes, no cimo dos montes, onde tudo respira vida e liberdade, no íntimo do lar doméstico, por toda a parte, em suma, depara-se-lhe o sinistro aspecto do escravo, exalando um gemido de dor, que é ao mesmo tempo uma imprecação e um protesto. E junto do negro o azorrague, o tronco e a força, trípode lúgubre em que se baseia a prosperidade do meu país! Oh! não! Cada dia que continua este estado de coisas, é uma cusparada que se lança à face da civilização e da humanidade! Sei que me acoimarão de idealista, alegando que não se governam nações com sentimentalismos e retóricas. Pois bem, há um fato incontroverso e palpável, que vem corroborar as minhas utopias. É sabido que os imigrantes estrangeiros não procuram o Brasil ou não se 
conservam nele, por não quererem emparceirar-se com os escravos. A escravidão é uma barreira insuperável à torrente imigratória. Portanto penso que só há uma solução para o problema da transformação do trabalho: a espada de Alexandre! (AZEVEDO, 1985, p. 199).

Nessa longa fala ecoam diversos argumentos correntes do ideário abolicionista hegemônico, dirigido para os problemas macroeconômicos decorrentes do regime escravocrata e coroado pelo incentivo à imigração estrangeira - em outras palavras, europeia -, não se detendo no problema da ressocialização e inserção dos ex-escravos no mercado de trabalho.

No artigo "O bom escravo e As vítimas-algozes", Brito Broca formula a hipótese de que a propaganda abolicionista foi formalizada na literatura romântica brasileira por duas vias distintas, sendo que uma delas apresentava

o escravo como uma criatura cheia de virtudes, superando os males da instituição; noutra mostrando-o como um ser infeliz e miserável, levado ao vício ou ao crime por culpa exclusiva do cativeiro. No primeiro caso temos uma imagem idealizada e romântica do negro, que o torna até superior ao branco. No segundo, uma imagem realista: o escravo dificilmente poderia ser bom na condição nefanda a que o relegava o cativeiro (BROCA, 1979, p. 271-273 apud FARIA, 2013, p. 95).

Partindo dessa premissa, podemos ler tanto Joana quanto Lourenço como indivíduos virtuosos, que, apesar da escravidão, mantêm sua dignidade e sua integridade. Joana abdica de sua liberdade, Lourenço abdica de suas economias e ambos rasgam papeis importantes em cena: a própria alforria, no caso da mãe-escrava de Jorge, e a letra falsificada pelo filho, no caso do pai-escravo de Gustavo, que se responsabilizaria por sua dívida.

Para além disso, podemos derivar duas outras categorias da hipótese de Broca por meio de uma inversão, encontrando o "bom senhor" e o "mau senhor", categorias separadas por uma distinção tênue. Assim, temos Jorge e Lima, em Mãe, e Gabriela e Carolina, em $O$ escravocrata, como senhores piedosos - e, em boa medida, idealizados - que protegem não os escravos, mas escravos em particular, aos quais se vinculam por laços de afeição - o que não redunda na supressão do laço de propriedade. No âmbito dos maus senhores, temos tanto as figuras dos "burgueses escravocratas", como o usurário Peixoto e o escravocrata Salazar (orbitado por funcionários, pelo sócio Sebastião e pela irmã Josefa), quanto a figura de Gustavo, que esboça, em um trajeto brusco, alguma redenção, atribuindo ao meio vicioso a causa para seus desvios morais.

Sendo assim, as duas peças tensionam a questão da escravidão de diferentes formas e plasmam contradições sociais amplamente debatidas na segunda metade do século XIX. Mãe apresenta a escravidão como problema a ser resolvido pelos "bons" senhores de escravos em uma perspectiva reformista e paulatina que não tem por intuito ofender as relações de propriedade. Esse posicionamento encontraria eco, por exemplo, na Lei do Ventre Livre, promulgada em 1871 pelo gabinete conservador de Rio Branco, que, ainda que tenha abalado a estrutura do regime escravocrata, lhe dava ainda algum fôlego. Em $O$ escravocrata, por sua vez, temos a escravidão representada com toda a sua torpeza, levando os personagens escravocratas às raias da caricatura. Contudo, o anticlímax final se constitui como saída um tanto conformista, sugerindo uma sublevação que ainda não se completa. Ainda assim, a revolta dos escravos não deixa de prenunciar a intensificação do apoio a fugas e de ações de desobediência civil que, conforme Angela Alonso (2014), teria como estopim o recrudescimento da repressão aos movimentos abolicionistas realizada pelo gabinete Cotegipe em 1885. 


\section{REFERÊNCIAS}

ABOLICIONISTA... Gazeta de Noticias, Rio de Janeiro, ano 10, n. 147, p. 2, 26 mai. 1884. Disponível em: <http://memoria.bn.br/DocReader/103730_02/7009>. Acesso em: 15 ago. 2017.

ALENCAR, José de. Mãe. 3. ed. revista. Rio de Janeiro: Garnier, 1940 ?.

ALONSO, Angela. O abolicionismo como movimento social. Novos Estudos CEBRAP, São Paulo, n. 100, nov. 2014, p. 115-137. Disponível em:

$<$ http://novosestudos.uol.com.br/wpcontent/uploads/2017/03/07_abolicionismo.pdf.zip>. Acesso em: 15 ago. 2017.

AUERBACH, Erich. Mimesis: a representação da realidade na literatura ocidental. São Paulo: Perspectiva, 2011.

AZEVEDO, Artur; DUARTE, Urbano. O escravocrata. In: AZEVEDO, Artur. Teatro de Artur Azevedo II. Rio de Janeiro: Instituto Nacional de Artes Cênicas, 1985.

COUTINHO, Afrânio (Org.). A polêmica Alencar-Nabuco. Introdução de Afrânio Coutinho. Rio de Janeiro: Tempo Brasileiro, 1965.

FARIA, João Roberto. Teatro romântico e escravidão. Teresa: revista de Literatura Brasileira, São Paulo, n. 12-13, p. 94-111, 2013. Disponível em:

<https://www.revistas.usp.br/teresa/article/view/99061/97567>. Acesso em: 15 ago. 2017.

RANCIÈRE, Jacques. A partilha do sensível: estética e política. 2. ed. Tradução de Mônica Costa Netto. São Paulo: EXO experimental org.; Ed. 34, 2009. O efeito de realidade e a política da ficção. Tradução de Carolina Santos. Novos Estudos CEBRAP, São Paulo, n. 86, mar. 2010, p. 75-90. Disponível em: $<$ http://novosestudos.uol.com.br/wpcontent/uploads/2017/03/05_Ranciere_p74a91.pdf.zip>. Acesso em: 15 ago. 2017. SCHWARZ, Roberto. A importação do romance e suas contradições em Alencar. In: Ao vencedor as batatas: forma literária e processo social nos inícios do romance brasileiro. São Paulo: Duas Cidades; Ed. 34, 2000.

SIMÕES, David. Liberdade e civilização no pensamento político de José de Alencar. Perspectivas, São Paulo, v. 40, p. 177-199, jul./dez. 2011. Disponível em: <https://periodicos.fclar.unesp.br/perspectivas/article/view/4835/4082>. Acesso em: 31 out. 2018. 